\title{
An Appraisal of Nigeria's Progress in Achieving the SDG-13 Climate Action Goal
}

\author{
Salamatu J. Fada ${ }^{1,2}$, Elijah A. Akintunde ${ }^{1}$, Simi S. Goyol ${ }^{1}$, Nankap L. Binbol ${ }^{1}$, Leonard Bombom ${ }^{1}$, Daniel D. \\ Dabi $^{1}$, Gideon Baklit ${ }^{1} \&$ Christian Y. Oche ${ }^{1}$ \\ ${ }^{1}$ Department of Geography and Planning, University of Jos, Nigeria \\ ${ }^{2}$ School of Natural Sciences, Bangor University, UK \\ Correspondence: Salamatu J. Fada, Department of Geography and Planning, University of Jos, Nigeria. E-mail: \\ saly_fada@yahoo.com
}

Received: January 4, 2022

Accepted: February 4, $2022 \quad$ Online Published: February 6, 2022

doi:10.5539/jsd.v15n2p66

URL: https://doi.org/10.5539/jsd.v15n2p66

\begin{abstract}
The impacts of climate change on the planet are increasingly felt with projections suggesting even greater impacts in the immediate term and, as such, the need for concerted efforts directed at curbing them. Although Nigeria battles with huge development needs, and its economy is confronted with a rapidly deteriorating fiscal space and rising levels of debt, the country has shown commitment to achieving the United Nations 2015 Sustainable Development Goals (SDG) by 2030. This situation creates a gap between the SDG agenda and the workability of the goal. This paper appraises efforts made by Nigeria's Federal Government to achieve the Climate Action Goal by 2030. The country's level of implementation of the set SDG 13 was, first, evaluated using the Environmental Performance Index (EPI). Subsequently, the role of the Anthony Nyong Climate Centre of Excellence (ANCCE) towards achieving the SDG 13 was explored. Results from the 2018 EPI scorecard ranks Nigeria 100th (54.76\%) out of 180 countries on 24 performance indicators across ten categories covering environmental health and ecosystem vitality. Similarly, results from SDG index and dashboard, places Nigeria at 42nd (47.07\%) out of 56 African countries. Even though these results show that 'challenges remain' in achieving climate action, Nigeria is on track toward achieving the SDG agreement. Furthermore, the establishment of ANCCE has so far achieved building of partnerships with organizations and other universities locally and internationally, capacity building among academics and the establishment of a waste management project in a tertiary institution in the country. A bottom-up approach aimed at achieving Climate action through activities of similar centers that can provide insight into a country's best practices and contribute in many ways to achieving the SDG 13 in Nigeria are suggested.
\end{abstract}

Keywords: Anthony Nyong, environmental performance index, sustainable development goals, climate change

\section{Introduction}

Negative impacts of climate change on national economies, human lives, rates of migration and frequencies of extreme weather events are on the increase, globally (IPCC, 2001; Leary et al, 2008; IPCC, 2014). The need for concerted effort to curb these trends is amplified by projections of imminent and even greater impacts (Leary et al, 2008; Dabi, Nyong, Adepetu, \& Ihemegbulem, 2008). Evidence of such impacts in Nigeria have been investigated over the last two decades for such areas as agriculture (Apata, Samuel \& Temidayo, 2009; Mertz, et al, 2009; Jidauna, Dabi, \& Dia, 2011), the environment (Mertz, et al, 2009, Odjogu, 2010; Mertz, et al, 2012), water resources (Dabi, 2000; Nyong, Dabi, \& Dung, 2003; Dabi, 2006; Fada, Dabi, \& Muhammed, 2018), population and health ( Dongurum, Gwamzhi, Goyol, Daloeng, \& Dabi, 2016; Wambai, Dabi, et al, 2017; Akintunde, 2017; Watts, et al, 2018), education ( UNESCO, 2015; NEA, 2020) conflicts (Fasona, Omojola, Adeaga, \& Dabi, 2007; Dabi, \& Jidauna, 2010, Sayne, 2011), and wetlands (Dabi, 2006; Nwankwoala, 2012) and similar studies are ongoing. Findings from these studies collectively suggest likelihood of shortages in resources and increased hardships throughout the 21 st century due to these negative impacts.

To curb projected adverse climate change in the country, Nigeria made concerted efforts to contribute to the global discussion on climate change. For over 25 years, the United Nations Framework on Convention of Climate Change (UNFCCC) has been making efforts and recording achievements in the evolution of international climate policy (UNFCCC, 2015). Consequently, in 2015 at the COP 21 the Paris Agreement was adopted by 195 nations to combat climate change and release actions and investment towards a low-carbon, resilient and sustainable future. 
Furthermore, the 17 Sustainable Development Goals were also agreed on at the same meeting (UNFCCC, 2015). Although Nigeria signed the Paris Agreement and committed to achieving the United Nations 2015 Sustainable Development Goals by 2030 (FGN \& UNICEF, 2017; UNDP, 2020), the nation battles with huge development needs, and her economy faces a rapidly deteriorating fiscal space with rising levels of debt. Additionally, recent realities relating to the emergence and impact of COVID-19 directly on cash on petroleum resources, adding further stress on the National economy which translates to poverty and livelihoods negatively affected.

Sachs et al. (2020) reports that the short-term impacts of coronavirus on climate Action, particularly SDG 13 are uncertain but revealed through reductions in global GHG emissions, pressure to reduce environmental safeguards, lack of clarity on environmental investments, slowdown in economic growth, contributing to reduction in energy prices which might increase access to energy but reduce incentives for renewables.

One of the current biggest concerns of the United Nations (UN) is the health crisis the world faces. However, the UN continues to call for attention to be fixed on the framework of action, the 2030 Agenda for SDG and the Paris Agreement on Climate Change (UNDP, 2020). Similarly, Guterres (2020) states that 'We must' keep our promises to the people and planet' by ensuring to stay on track on the fight to combat climate change.

Although the UN 17 SDGs provide a framework for action, complementary actions to be provided by Governments, Researchers, Civil Societies, and Businesses from all 194 countries involved are expected. So far, there exist the absence of shared understanding on how the goals can be initiated (Sachs et al 2019).

In Nigeria, higher institutions and research institutes must play the important role of providing knowledge base for designing, implementing, and monitoring the SDG 13. Their role will fuel National governance and policy making on climate as well as identify missing gaps in potentials for climate research and studies. Akinbami and Akinbami (2017) suggest in their study that positive measures of achievement from research evidence could shape climate policy and management while exposing challenges and missing gaps which should attract university researchers in Nigeria. This paper therefore appraises the role of education in achieving SDG 13 in Nigeria and highlights the activities of Universities and research institutions as collaborators.

\section{Overview of SDG 13 and Its Implementation in Nigeria (From Office of the SA on President on SDGs, UN Platforms)}

The implementation of SDG 13 in Nigeria has witnessed some measure of progress although a lot still needs to be done to fully achieve this goal. The specific targets and progress made for achieving the SDG 13 are provided in Table 1 The specific targets, as highlighted in Table 1.

Table 1 . The progress made by Nigeria in achieving SDG 13 goals

\begin{tabular}{lc}
\hline Goal $\quad$ Specific Target & Progress made \\
& (Insignificant, Little, Significant, Great Progress) \\
\hline
\end{tabular}

13.1 Strengthen resilience and adaptive capacity to climate-related hazards and natural disasters in all countries

\section{Little progress}

The Federal Government of Nigeria has expressed its readiness to implement:

- the National Climate Change Policy and Response Strategy (NCCPRS) and

- the National Adaptation Strategy and Plan of Action for Climate Change Nigeria (NASPA-CCN 2011),
13.2 Integrate climate change measures into national policies, strategies, and planning

\section{Significant progress}

The Federal Government of Nigeria has:

- Established the Department of Climate Change, under the Federal Ministry of Environment.

- Adopted a comprehensive strategy policy on climate change, the 'Nigeria Climate Change Policy Response and Strategy' in 2012, though their application is limited by the lack of the required legislation (ORADI, 2020)

- Not enacted a specific climate change law that can provide a legal framework and enabling environment for the implementation of its climate action agenda.

- A Bill to establish the Commission is yet to be presented to the National Assembly (ORADI, 2020). 


\begin{tabular}{|c|c|c|}
\hline 13.3 & $\begin{array}{l}\text { Improve education, } \\
\text { awareness-raising and } \\
\text { human and institutional } \\
\text { capacity on climate change } \\
\text { mitigation, adaptation, } \\
\text { impact reduction and early } \\
\text { warning }\end{array}$ & $\begin{array}{l}\text { Significant progress } \\
\text { Nigeria has: } \\
\text { - Pledged to mainstream climate change into all sectors of the national economy. } \\
\text { - Promoted evidence-based research in climate change and raised awareness on } \\
\text { climate change mitigation and adaptation opportunities among stakeholders at } \\
\text { all levels. } \\
\text { - Strengthened its national climate change institutional structure and governance } \\
\text { to include active participation by the States and the Local Governments. An } \\
\text { example is the establishment of the ANCCE in University of Jos. } \\
\text { - In the } 2017 \text { Budget, made provision for forest regeneration like the planned } \\
\text { establishment of } 10 \text { hectares of Acacia-Senegal in Zamfara State to increase } \\
\text { forest cover and mitigate the effects of drought and climate change (ORADI, } \\
\text { 2020). }\end{array}$ \\
\hline
\end{tabular}

13.a Implement the commitment undertaken by developed-country parties to the UNF CCC to a goal of mobilizing jointly $\$ 100$ billion annually by 2020 from all sources to address the needs of developing countries in the context of meaningful mitigation actions and transparency on implementation and fully operationalize the Green Climate Fund through its capitalization as soon as possible

\section{Significant progress}

Nigeria:

- Set up the National Climate Change Trust Fund (NCCTF) and the Environmental Sustainability Group (ESG) to design and attract financing mechanisms for adaptation initiatives.

- Signed the Paris Agreement on the 22nd of September 2016, and on the 28th of March 2017, President Muhammadu Buhari signed the Instrument of Ratification of the Paris Agreement on Climate Change.

- Was not among the countries that had fully paid their 2017 contributions as required by the agreed financial policy that supports the crucial work of the UN climate body.

- However, instituted the first sovereign green bond in Nigeria and indeed in Africa in the third quarter of 2017 as one of the strategies for raising funds for implementing climate change initiatives.

13.b Promote mechanisms for raising capacity for effective climate changerelated planning and management in least developed countries and small island developing States, including focusing on women, youth and local and marginalized communities

\section{Significant progress}

Nigeria has committed to:

- Reducing its GHG emissions by 20 per cent relative to a business-as-usual scenario of economic and emissions growth by 2030.

- Pursuing a 45 per cent reduction of GHG emissions if sufficient international support is received. It intends to achieve this by ending gas flaring (burning of excess gas from oil and gas production), increasing the use of renewable energy, implementing climate-smart agriculture and championing reforestation efforts (MoE, 2015). A major effort in this regard is the announcement by the Department of Petroleum Resources (DPR), ordering about 9,000 filling stations across the country, to install facilities for gas products as an alternative fuel for Nigerians (Olisah, 2020).

Source: SDG Center for Africa (2019), SDG National Review (2017) and Oradi (2020)

Another policy of the Federal Government of Nigeria, contained in the SDG National Review document (FGN \& UNICEF, 2017) that would greatly impact the SDG 13 goals is the policy on environmental sustainability which has been articulated in section 5.6 of the (Nigeria Economic Recovery and Growth Plan (NERGP, date) with five stated objectives. These are promoting sustainable management of natural resources, addressing severe land degradation and desertification issues, attracting financing for projects on sustainable development, reducing gas flaring by 2 percentage points every year so that it is eliminated by 2020 as well as installing an additional 3,000 MW of solar systems over a period of 4 years, beginning in 2018. However, the covid -19 pandemic may have distorted and slowed down the process of achieving some of these targets.

The key strategies that are already defined in the NERGP towards actualizing these policy objectives, include the 
following nine specific strategies:

1) Increasing the number of households transiting from kerosene to cooking gas - that is, Liquefied Natural Gas (LNG) - to 20 per cent from the present value by 2020

2) Increasing the number of households replacing kerosene lanterns with solar lamps by 20 per cent by 2020

3) Implementing projects under the country's Great Green Wall initiative to address land degradation and desertification and supporting communities adapting to climate change (e.g., by planting trees)

4) Implementing environmental initiatives in the Niger Delta region of the country (for example, by continuing the Ogoni Land clean-up and reducing gas flaring)

5) Raising Green Bonds to finance environmental projects.

6) Establishing one forest plantation in each State of the Federation

7) Rehabilitating all forest reserves and national parks to enhance eco-tourism.

8) Establishing functional database on drought and desertification and

9) Encouraging and promoting the development of green growth initiatives.

\subsection{How Nigeria Stands, Compared with Other African Countries}

Regarding SDG 13, most of the countries in Africa have achieved goal 13 or are well on track to achieving it. While Nigeria is on course to achieving this goal, it remains one of the few countries that have existing challenges (Figure 1). Other countries in this category include Botswana, Seychelles, Namibia, Mauritius, Egypt, and South Africa. 
2020 SDG dashboards (levels and trends) for Sub-Saharan Africa

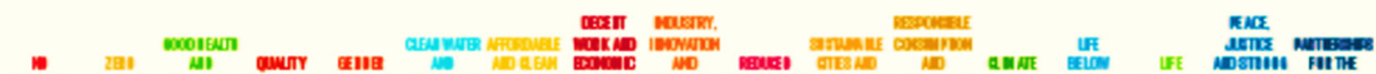

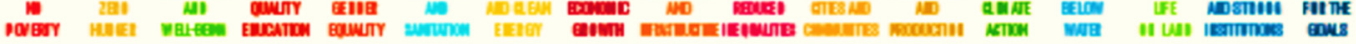

$\begin{array}{lllllllllllllllll}1 & 2 & 3 & 4 & 5 & 6 & 7 & 8 & 9 & 10 & 11 & 12 & 13 & 14 & 15 & 16 & 17\end{array}$

Angola

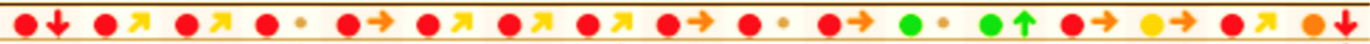

Berin

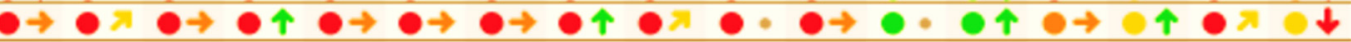

Botswana

Burkina Faso

Burundi

Gabolerde

Cameroon

Central African Reppublic

Chad

Comoros

Conga Rep.

Cote dhore

Dem Rep.Congo,

Dibouti

Equatcrial Gunea

Eritrea

Eswatini

Ethiopia

Gabon

The Gambia

Ghana

Gunea

Guinea-Bissau

Kente

Lesotho

Liberia

Madagascar

Malaw

Mali

Mauritania

Mavinius

Macambique

Namibia

Niger

Nigeria

Riwanda

Sło Tơné and Principe

Senegal

Seychelles

Serra Leone

Somalia

South Africa

South Sudan

Sudan

Tanzania

Togo

Uganda

Zambia

Znmbabwe

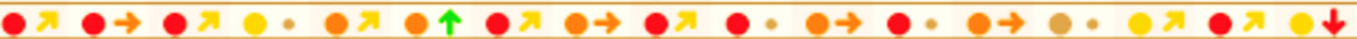

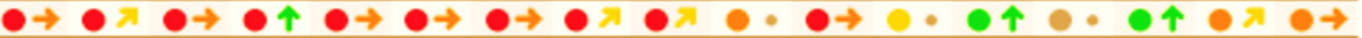

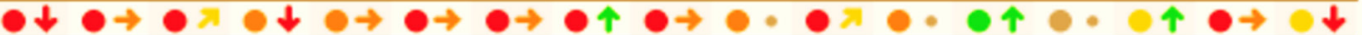
○ ○ $\rightarrow$ Q $\rightarrow$ Q $\rightarrow$ 个 个

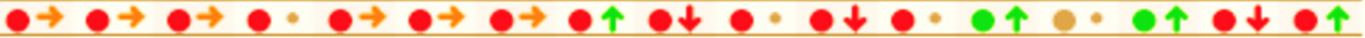

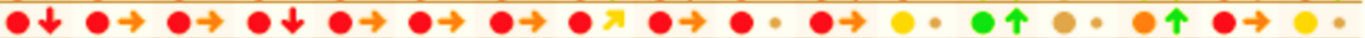

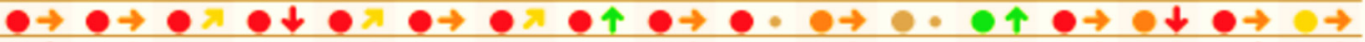

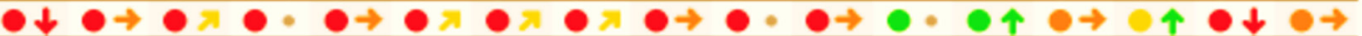

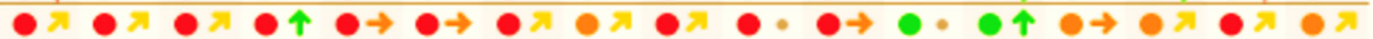

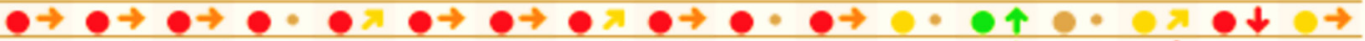

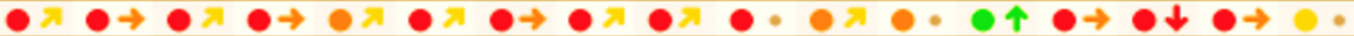
.

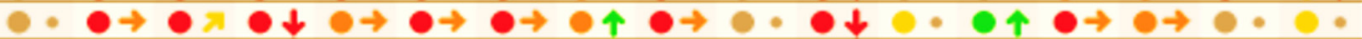

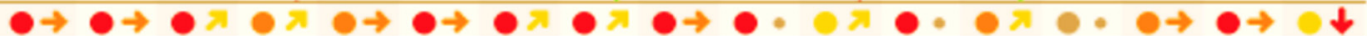

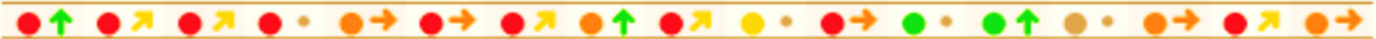
○

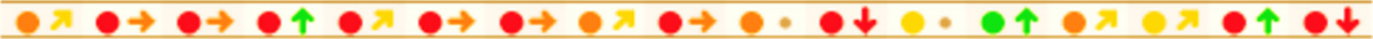
○ ○

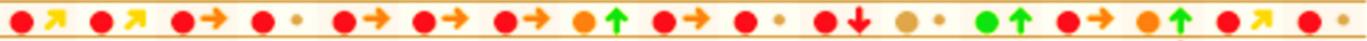

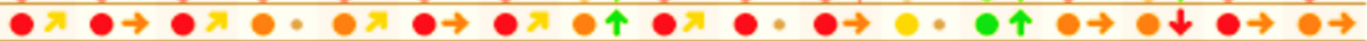

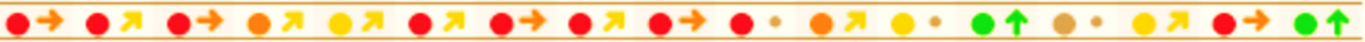

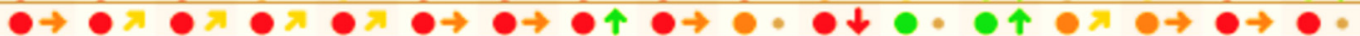

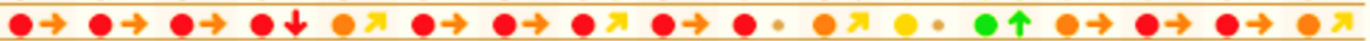

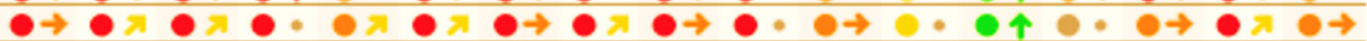

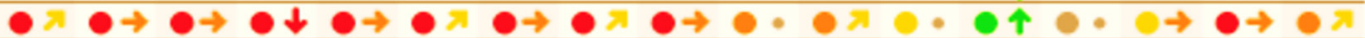

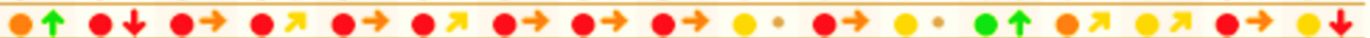

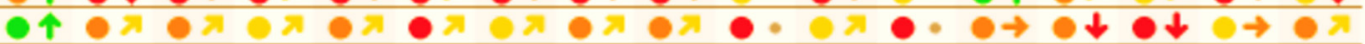

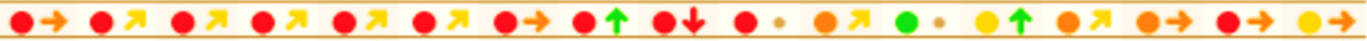

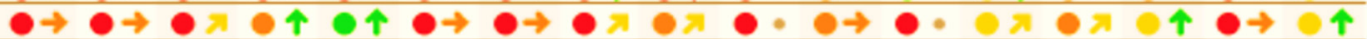

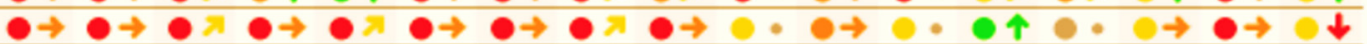

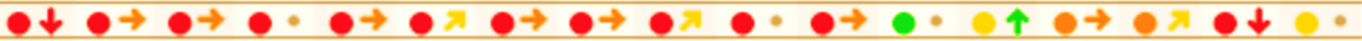

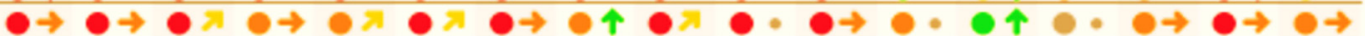
○ ○

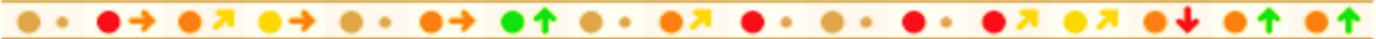

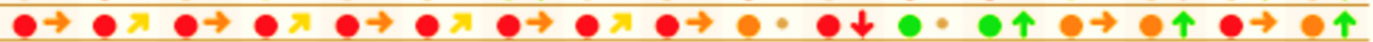

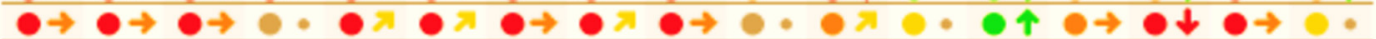
$\varphi \rightarrow 0$ 중

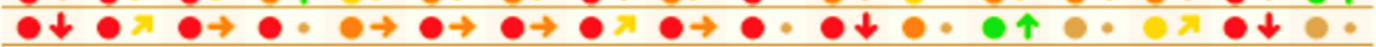

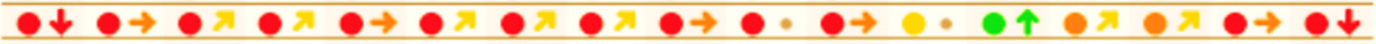

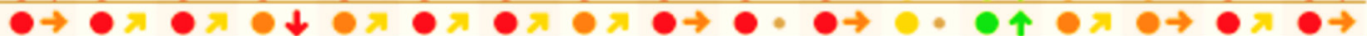

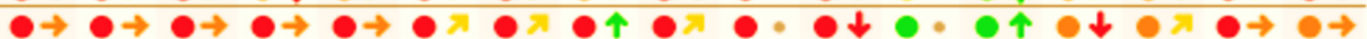

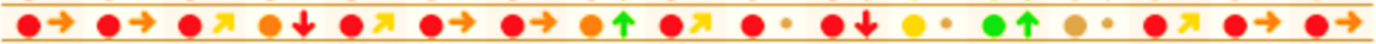

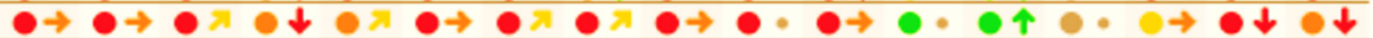

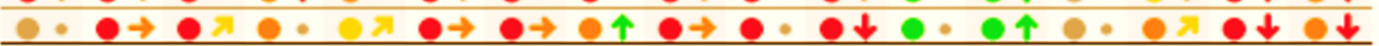

\footnotetext{
SDG axheroment

Challenges remain

- Significant challenges remain

$\uparrow$ On tradk

त. Moderatoly Incoasing

$\rightarrow$ Stagnathg
}

- Major challenges remain

$\downarrow$ Decreasing

Data not avaltable

sane, Autrers unuts:

Figure 2. 2020 SDG Databoard (level and trends) for sub-Sahara Africa 
Furthermore, Territorial $\mathrm{CO}_{2}$ emission from Nigeria is so high compared to other parts of the continent that only 3 countries in Africa boast of higher emissions namely, South Africa, Egypt, and Algeria (Figure 3).
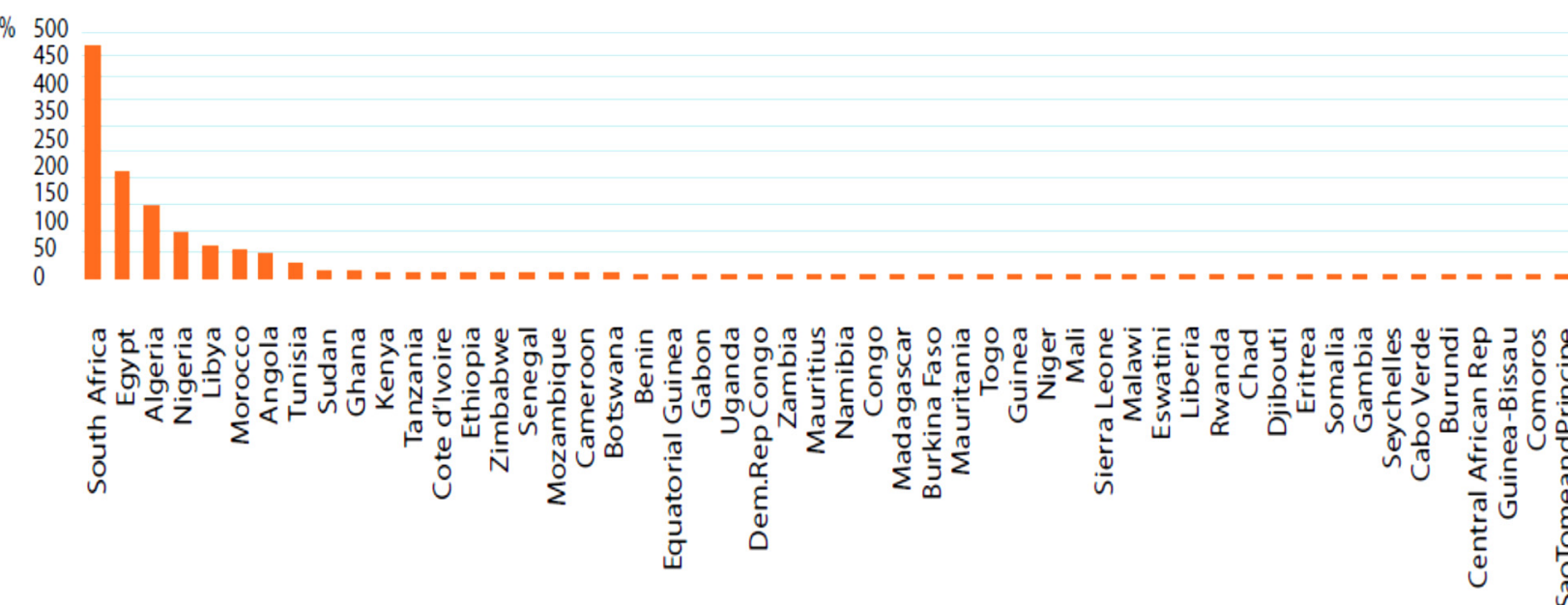

Figure 3. Territorial CO2 emissions (2016)

Source: SDG Center for Africa (2017)

\section{The Link between SDG 13 and Other SDGs (Especially SDG 12)}

Climate Change is largely driven by anthropogenic activities. However, with the advent of the coronavirus (COVID 19) pandemic, new challenges have been introduced. For example, combating COVID-19 without clean water (Besty, Samanta, Colins \& Marlena, 2020) and the need to provide safe water, sanitation, and hygienic conditions for protecting human health during all infectious disease outbreaks and COVID-19 (WHO, 2020). Consequences of lockdowns globally during the COVID-19 pandemic may be associated with other benefits such as reductions in emissions which gives assurance in the climate action domain. There are undoubtedly interlinkages between the SDGs, which Tosun and Leininger (2017) describe as "integrated and indivisible." These interlinkages produce both synergies (co-benefits) and trade-offs. Understanding the interactions between SDGs therefore is important to policy coherence and focused prioritization of action plans for achieving large synergistic impacts (UN-DESA, 2018). According to Tosun and Leininger (2017), SDG13 is incorporated in nine other SGDs, which is the highest number of connections. Several targets of SDG13 have significant ties to SDGs 1, 2, 3, 7, 9, $11,12,14$ and 15 .

The inter-link between SDG13 and SDGs 1 and 2 is mutually reciprocal. Appropriate adaptations to climate change are required to enhance food production to end hunger (SDG2) and poverty (SDG1). Reversely, climate change leads to extreme weather events that significantly impact on the achievements of SDG2 and, by extension, SDG1. Unsustainable agricultural practices are responsible for about $24 \%$ of anthropogenic greenhouse gases emissions which have profound effect on climate change (IPCC, 2014).

The impact of SDG13 on health (SDG3) is manifold. In many parts of the world, climate change has threatened food and water security, caused mass movements of people, and has promoted the spread of diseases. These have consequences on nutrition, health and well-being and morbidity and mortality. Clean water (SDG6) if/when attained and climate action will reduce the spread of infectious diseases and ensure better health (Watts, 2018). There is also a potential for increase in conflicts as people leave unfavourable climatic areas for others and thereby increase pressure on available resources. Increasing dependence on fuel wood and similar derivatives such as charcoal and biochar in most of Northern Nigeria has resulted in increased desertification, worsened also by harmful agricultural practices, all of which may be fingered for the desperate southerly press by herdsmen in search of greener pastures; the consequences are manifest as perennial and recurrent violent clashes and wanton loss of innocent lives and property all over Nigeria. The implication on farm productions in crises ridden areas can only continue to increase.

Heat stress has also impacted on the health and ability of people to work productively. People in Maiduguri move about with drinking water to mitigate these effects, even when it is to ensure that they are able to urinate. A reduction in air pollution due to combustion of fossil fuel will benefit both climate change and health (Howden- 
Chapman, 2017).

The increasing use of renewable energy as targeted by SDG7 will benefit the achievement of SDG 13. This will not only reduce greenhouse emissions but will also checkmate rise in global temperatures (Mollier et al., 2017; Nilson et al., 2018). The use and expansion of modern energy services, while fully ensuring the achievement of SDG7, is not inimical to climate change action since emission estimates that would result are low (McCollum et al., 2017). Increase in the use of energy-efficient technology will advance the attainment of set goals in many fronts including ending poverty (SDG1), achieving zero hunger (SDG2) and combating climate change (SDG13). In the same vein, the elimination of fossil fuel subsidies is targeted at reducing wasteful production and consumption (SDG12), which directly relate to energy use (SDG7) and climate action (SDG13). Carbon emissions and other greenhouse gases would be significantly reduced with less consumption of fossil fuels (Schroeder et al., 2019).

Upgrading infrastructure and increasing resource use and efficiency of industry are beneficial to climate action as well (Tosun \& Leininger, 2017). This is especially so in relation to cities where a lot of the anthropogenic contributions to climate change are found. The adaptation and mitigation of climate change policies and action plans in cities will greatly aid in the achievement of SDG13.

Similarly, the interaction between SDGs 13 and 14 are highly synergistic. Climate change significantly affects marine life as such resources and the conservation and use of these marine resources for sustainable development may be more easily accomplished by achieving the goals of climate change action (SDG13). Coastal ecosystems act as important carbon sinks and their conservation would ensure climate regulation (Schmidt et al., 2017). The coastal ecosystems are important contributors to climate change adaptation, climate hazard mitigation, reducing risks and vulnerabilities and thereby strengthening the resilience of coastal communities. Addressing climate change also benefits the marine ecosystem by reducing ocean acidification which results from increased levels of carbon dioxide in seawater.

Due to these interlinkages, climate change remains a vital pivot around which the achievement of the SDGs revolves. Policies and action plans must be geared towards an integrated approach towards the attainment of SDGs. Climate change, by virtue of its multiplier effects on other SDGs should be given prominence and placed at the top of the priorities of all SDG implementation agencies.

\section{The Role of Education towards Achieving SDG 13}

SDG Goal 4: Quality Education aims at ensuring inclusive and equitable quality education and promoting lifelong learning opportunities for all (UNDP, 2020). Universities are at the apex of ensuring quality education, training qualified teachers for secondary and tertiary institutions in the country. Other tertiary institutions like colleges of education and polytechnics train primary school teachers. Overall, universities train the manpower needed in other sectors of the economy.

According to UNESCO (2015), Climate change education (CCE) aims at addressing and developing effective responses to climate change. It helps learners to (i) understand the causes and consequences of climate change, (ii) live with the impacts of climate change, and (iii) take appropriate actions towards adopting more sustainable lifestyles. It helps policymakers to understand the need for and importance of urgently providing mechanisms/strategies for combating climate change at both national and global scales. It also helps communities to learn about the effects of climate change on their livelihoods (vulnerabilities), develop strategies for protecting themselves from negative consequences (adaptation) and reduce their carbon emission and climate footprint (mitigation).

Education is, therefore, necessary for understanding the impacts, vulnerabilities, and adaptation to climate change. Consequently, the strategies to take to meet the targeted climate action (SDG 13) requires quality education (SDG 4). However, ensuring that everyone has an equal opportunity for educational progress remains a challenge worldwide (UNESCO, 2019). Without the required education for all, achieving SDG 13 and other goals remain a mirage.

\section{ANCCE - Anthony Nyong Climate Centre of Excellence}

Having realised the role education plays in understanding and addressing the challenges of climate change, the Nigerian university system has made concerted efforts towards strengthening Climate Change Education. In order to have a broader view of the causes, impacts and vulnerabilities of climate change and also to align sectors to build resilience against adverse climate change, specific measures are adopted by the ANCCE. These include developing curriculum geared towards effective response to climate change, interdisciplinary and multidisciplinary approach to climate change adaptation, and supporting local experts to explore and fabricate items through 
innovative learning.

\subsection{Curriculum Development}

ANCCE is developing expertise towards quality, forward thinking, creative and balanced learning. Curriculum developed are geared towards giving students a broad knowledge of climate change related issues including causes and consequences, mitigation, adaptation, and resilience as well as climate change governance.

1) Introduction of climate related courses at undergraduate level: Two climate related courses - 'Introduction to Environmental Hazards' and 'Environmental Health and Hazards' - were introduced in the Geography and Planning curriculum of at least one Federal University in the country. This has expanded the scope of climate change education and consequent increase in the number of undergraduate final year projects in Climate related issues.

2) Creation of climate research cluster groups: At the moment, masters' students embarking on final projects related to climate change are clustered into several groups targeted at climate change mitigation and adaptation. Research projects have so far produced local evidence of climate change and further research is on to provide location specific adaptation measures.

3) Currently, there are plans to expand postgraduate programmes to offer climate change studies at master's level.

\subsection{Interdisciplinary and Multidisciplinary Training}

Expanding the scope of training in climate change education is relevant to improving capabilities, capacities, productivity, and performance.

Due to the interconnected and interrelated nature of global systems, ANCCE recognises the need to improve interdisciplinary/multidisciplinary training. As such, the centre has so far achieved the following.

1) Intensive training of researchers: academics are engaged to develop research projects with professionals and other academics from different universities both in Nigeria and internationally. Locally, the call for Tertiary Education Trust Fund (TETFund) Institution Based Research (IBR) intervention has offered the ANCCE opportunity to produce an increasing number of collaborations for joint climate research projects with fellow colleagues across faculties of the University of Jos. Internationally, one project worthy of mention is the AIRCCC collaboration between the French government and Nigerian Universities where academics from the ANCCE were engaged in training workshops with French professionals and other academics from six other universities across Nigeria through which joint research projects were initiated.

2) Innovative ideas exchanged across disciplines.

\subsection{Supporting Local Technologies and Experts, SMEs in Building CC Resilience}

The ANCCE in its pursuit to address the global problems associated with climate change and to scale up local/micro conditions of climate change peculiar to the Jos Plateau, the regional and global situations has been able to collaborate with Communauté Université Grenoble Alpes in France. This collaboration led to the establishment of a Fabrication Laboratory in the University of Jos in conjunction with the AIRACC team. ANCCE is currently supporting local technologies and experts, SMEs in building Climate Change resilience and taking advantage of opportunities in innovation and fabrication of equipment that will address educational awareness and institutional capacity on climate change mitigation, adaptation, impact reduction and early warning. Some of these projects underway include:

\subsubsection{Biomass Energy Generation and Utilization}

This project comprises two basic units namely, a biodigester for generating cooking gas for domestic consumption and a gasifier. The technology is capable of utilising all plant and animal matter such as residues from farms, crops, trees, and animal faecal matter.

\subsubsection{Solar Powered Irrigation Technology}

An automatic irrigation system powered using solar energy. Most components can be locally sourced and fabricated while others may be locally assembled.

\subsubsection{Microcontroller for Energy Management}

This is a small device with a user-friendly android application for energy management in homes and offices targeted at saving energy for homeowners and institutions, built using the Arduino Microcontroller for Energy Management. 


\subsubsection{An Omnidirectional Agric-Robot}

The Omnidirectional Agric-Robot will be used for Soil and Weather Data Collection and also for real-time monitoring of soil and weather conditions for informed decision-making during farming activities. These robots are efficient for planning farm operations and ensuring optimum crop production. An autonomous Agric-robot prototype can be constructed using Arduino micro-controller in the Fab Lab. Miniature models of some prototypes may be achieved, however.

\subsubsection{Solar Dryer Technology}

Uses the solar energy to reduce the moisture content of farm produce and can be fabricated using local materials. The solar dryers can be produced in the Fab Lab.

5.4 Fourth Industrial Revolution (How Nigeria Can Create the Opportunities through Artificial Intelligence, Drones, Machine Learning etc.) and Be Linked to Youth Empowerment

The contributions of ANCCE will go a long way in helping Nigeria to achieve SDG 13 and join the League of Nations spearheading the Fourth Industrial Revolution through the innovations and production of equipment that use Artificial Intelligence (AI). This equipment will reduce Green House Gas (GHG) emissions, fuels from renewable sources and additional supply of organic manure. It will also enhance energy and water use for agricultural, domestic, and industrial use. The centre will also help to reduce the extents of vulnerabilities of poor rural households and the citizenry. Finally, the centre will mass produce the equipment toward smart climate change adaptation and mitigation in Nigeria and globally.

\section{Conclusion}

Climate change is a matter of global concern such that different countries have put in place platforms of action to handle the issue from well-informed scientific, acceptable, and internationally recognised practices. The discussions at the world bank Spring summit of 2021 centered around major priorities for COP26 with the Green resilient recoveries to support poverty reduction, promote sustainability and present great opportunities and mainstreaming of Climate considerations into Energy, Transport, and Agriculture land uses, Urban and Manufacturing sectors. The key green transitions proposed will include New Climate Action Plan (starting with countries NDC's climate diagnostics) which will address such important areas like increase ambition for climate finance, co - benefits - impacts and outcomes and the need to get the private sector involved.

There are several tools available to support such green recoveries. The Nature-based Solution (NbS) is such tools as we recognize that the challenges of nature loss and global warming are linked - but so are their solutions. That is why, it is beneficial to embrace the concept of $\mathrm{NbS}$.

In Nigeria, the government has responded by establishing a department of climate change, National Climate Change Trust Fund and the National Climate Change Act was also signed into Law in October 2021. However, combating climate change requires sustainable actions promoted through strong political will, enactment of specific and implementable legislations on the environment, inclusive participation of all key stakeholders, and the use of environmentally renewable sources with energy-efficient technology to harness biomass or solar energy. In addition to closing these gaps, providing adequate funding, and mainstreaming of climate change into curricula at all levels of education but particularly at the tertiary level with adequate budgetary provision is very necessary. Education is a major driving force. No nation grows and develops without the provision of quality education for its citizens.

Deliberate actions or efforts must be made to seek for sustainable solutions towards combating climate change in view of its global impact and deleterious effects on humanity. To achieve this, a systems approach targeted at involving relevant instruments, agencies and collaborations is favoured. Collaborations at local and international levels such as that pushed through by the ANCCE would produce workable documents through research and development and promote human capacity building, adaptation and mitigation of climate change as well as eventual control of GHG emissions, as well as the adverse effects of anthropogenic practices, guaranteeing secure ecosystems and promoting environmental health not only for the present but for generations yet unborn.

\section{References}

Akinbami, J. F. K., \& Akinbami, C. A. O. (2017). Climate Change Mitigation and Adaptation Studies in Nigeria Universities: Achievements, Challenges and Prospects. In Leal Filho W. (Eds.), Climate Change Research at Universities. Springer, Cham. https://doi.org/10.1007/978-3-319-58214-6_9

Akintunde, E. A. (2017). Theories and Concepts for Human Behavior in Environmental Preservation, Review Article. Journal of Environmental Science and Public Health, 1(2), 120-133. 
https://doi.org/10.26502/jesph.96120012

Apata, T. G., Samuel, K. D., \& Adeola, A. O. (2009). Analysis of Climate Change Perception and Adaptation among Arable Food Crop Farmers in South Western Nigeria (No. 1005-2016-79140).

Besty, O., Samanta, K., Colins, S., \& Marlena, C. (2020). Combating the coronavirus without clean water. Retrieved November 12, 2020, from http://www.preventionweb.net

Dabi, D. D. (2000). Rural water resources' management problems in Katarko, a semi-arid village in northern Nigeria. Journal of Environmental Sciences, 4(1), 103-111.

Dabi, D. D. (2006). Assessing the Vulnerability of Fadama (Floodplain) Agriculture to Climate Variability and Change: A Case Study of Semi-arid Northern Nigeria. A research report Submitted to Global System for Analysis, Research and Training (START) International Secretariat, Washington, DC., USA. March 2006. $25 \mathrm{pp}$.

Dabi, D. D., \& Jidauna, G. G. (2010). Climate change and local perception in selected settlements in SudanoSahelian region of Nigeria. Journal of Environmental Sciences and Resource Management, 2, 1-12. Retrieved from http://www.cenresin.org

Daggash, H. (2018). Nigeria and Climate Change, Global Trends and Local Challenges. Retrieved from https://republic.com.ng/junejuly-2018/nigeria-climate-change/

David, M. D., Echeverri, L. G., Riahi, K., \& Parkinson, S. (2017). SDG 7 Ensure access to affordable, reliable, sustainable, and modern energy for all. In D. J. Griggs, M. Nilsson, A. Stevance, \& D. McCollum (Eds.), $A$ Guide to SDG Interactions: from Science to Implementation. International Council for Science, Paris, France.

Development Goals: Approaches to Attain Policy Integration. (2017). Global Challenges, 1(1700036), 1-12. https://doi.org/10.1002/gch2.201700036

Dongurum, C. K., Gwamzhi, R. J., Goyol, S. S., Daloeng, H. M., \& Dabi, D. D. (2016). Population characteristics, vulnerability to climate change and sustainable livelihood of rural households the Sahel region of Nigeria. Jos-Plateau Journal of Environmental and Sustainable Development, 1(1), 74-96.

Fada, S. J., Dabi, D. D., \& Muhammed, N. Z. (2018). A survey of water sources for households around the Yankari Game Reserve, Nigeria. International Journal of Innovative Research and Development, 7(2), 33-37. https://doi.org/10.24940/ijird/2018/v7/i2/DEC17042

Fasona, M., Omojola, A., Adeaga, O., \& Dabi, D. (2007) Aspects of Climate Change and Resource Conflicts in the Nigerian Savannah. IPCC TGICA Expert Meeting on Integrating Analysis of Regional Climate Change and Response Options. Denarau Island, Nadi, Fiji, June 2007. pp41-48.

Howden-Chapman, P., Siri, J., Chisholm, E., Chapman, R., \& Doll, C. N. H. (2017). SDG 3 Ensure healthy lives and promote well-being for all at all ages. In D. J. Griggs, M. Nilsson, A. Stevance, D. McCollum (Eds.), $A$ Guide to SDG Interactions: from Science to Implementation. International Council for Science, Paris, France. https://doi.org/10.24948/2017.01.03

IPCC. (2001). Climate Change 2001: The Scientific Basis. Contributions of Working Group I to the Third Assessment Report of the Intergovernmental Panel on Climate Change.

IPCC. (2014). Climate Change 2014: Synthesis Report. Contribution of Working Groups I, II and III to the Fifth Assessment Report of the Intergovernmental Panel on Climate Change Cambridge University Press.

Jidauna, G. G., Dabi, D. D., \& Dia, R. Z. (2011). The effect of climate change on agricultural activities in selected settlements in the Sudano-Sahelian Region of Nigeria. Archives of Applied Science Research, 3(6), 154-165.

Leary, N. et al. (2008). A Stitch in Time: General Lessons from Specific Cases. In N. Leary, J. Adejuwon, V. Barros, I. Burton, J. Kulkarni, \& R. Lasco (Eds.), Climate Change and Adaptation (Chapter 1, pp. 1-27). Earthscan, London, UK.

Måns-Nilsson, M., Chisholm, E., Griggs, D., Howden-Chapman, P., McCollums, D., Messerlis, P., Neumann, B., Stevances, A. S., Visbeck, M., \& Stafford-Smith, M. (2018). Mapping interactions between the sustainable development goals: lessons learned and ways forward. Sustainability Science, 13, 1489-1503. https://doi.org/10.1007/s11625-018-0604-z

Mertz, O., Bouzou, I., Diouf, A., Dabi, D., Nelsen, J. O., Diallo, D., Mbow, C., Ka, A., \& Maiga, A. (2009). Perceptions of environmental stress by rural communities in the Sahel-Sudan zone of West Africa. IOP Conference Series: Earth and Environmental Science, 6(41), 412032. https://doi.org/10.1088/1755- 
$1307 / 6 / 41 / 412032$

Mertz, O., D’haen, S., Maiga, A., Bouzou-Moussa, I., Barbier, B., Diouf, A., Diallo, D., Da, D., \& Dabi, D. (2012). Climate Variability and Environmental Stress in the Sudan-Sahel Zone of West Africa. AMBIO, 41(4), 380392. https://doi.org/10.1007/s13280-011-0231-8

Mertz, O., Mbow, C., Nelsen, J. O., Ka, A., Diallo, D., Cisse, P., Barbier, B., Da, D.E., Bouzou, I., Mato, V. M., Dabi, D., \& Ihemegbulem, V. (2009). Linking climate factors, agricultural development and adaptation strategies in the Sahel-Sudan zone of West Africa. IOP Conference Series: Earth and Environmental Science 6(2009), 2030. https://doi.org/10.1088/1755-1307/6/34/342030

Ministry of Environment, Federal Republic of Nigeria. MoE. (2015). Nigeria's Intended Nationally Determined Contribution. Abuja.

Mollier, L., Seyler, F., Chotte, J.-L., \& Ringler, C. (2017). SDG 2 End hunger, achieve food security and improved nutrition and promote sustainable agriculture. In D. J. Griggs, M. Nilsson, A. Stevance, \& D. McCollum (Eds.), A Guide to SDG Interactions: from Science to Implementation. International Council for Science, Paris, France. https://doi.org/10.24948/2017.01.02

NEA. (2020). Climate Change Education: Essential Information for Educators. National Education Association (NEA). Retrieved November 12, 2020, from https://www.nea.org/professional-excellence/studentengagement/tools-tips/climate-change-education-essential

Nwankwoala, H. O. (2012). Case studies on coastal wetlands and water resources in Nigeria. European Journal of Sustainable Development, 1(2), 113-113. https://doi.org/10.14207/ejsd.2012.v1n2p113

Nyong, A. O., Dabi, D. D., \& Dung, J. E. (2003). Siting rural water facilities: an assessment of their efficiency and equity in Katarko, Yobe State, Nigeria. International Journal of Ecology and Environmental Dynamics, 1(1), $1-15$.

Odjugo, P. A. (2010). Regional evidence of climate change in Nigeria. Journal of geography and regional planning, $3(6), 142-150$.

Olisah, C. (2020). Gas is the new petrol-FG to Nigerian car owners, FG is finding ways by which gas will become the preferred fuel for cars instead of petrol. Retrieved from https://nairametrics.com/2020/09/11/

ORADI. (2020). SDG 13: Climate Action: Nigeria's Progress Report. O-analytics Research and Development Initiative (ORADI). Retrieved from http://oradi.org/organisational-info/about-oradi.html

Sachs et al. (2020). The Sustainable Development Goals and Covid-19. Sustainable Development Report 2020. Cambridge: Cambridge University Press. https://doi.org/10.1017/9781108992411

Sachs, J. D. et al. (2019). Six Transformations to achieve the Sustainable Development Goals. Nat Sustain, 2, 805814. https://doi.org/10.1038/s41893-019-0352-9

Sayne, A. (2011). Climate change adaptation and conflict in Nigeria. US Institute of Peace.

Schmidt, S., Neumann, B., Warwern, Y., Durussel, C., Unger, S., \& Visbeck, M. (2017). SDG 14 Conserve and sustainably use the oceans, seas and marine resources for sustainable development. In D. J. Griggs, M. Nilsson, A. Stevance, \& D. McCollum (Eds.), A Guide to SDG Interactions: from Science to Implementation. International Council for Science, Paris, France. https://doi.org/10.24948/2017.01.05

Schroeder, P., Antonarakis, A. S., Brauer, J., Conteh, A., Kohsaka, R., Uchiyama, Y., \& Pacheco, P. (2019). SDG12 Responsible production and consumption - potential benefits and impacts on forests and livelihoods. In Katila, P., Colfer, C. J. P., Jong, W., Galloway, G., Pancheco, P., \& Winkel, G. (Eds.), Sustainable development goals: Their impacts on forests and people. https://doi.org/10.1017/9781108765015.014

SDG National Review. (2017). Implementation of the SDGs, A National Voluntary Review. Office of the Senior Special Assistant to the President, Sustainable Development Goals.

Tosun, J., \& Leininger, J. (2017). Governing the Interlinkages between the Sustainable.

UN-DESA. (2018). Advancing the 2030 agenda: Interlinkages and common themes at the HLPF 2018, An expert group meeting in preparation for HLPF 2018: Transformation towards sustainable and resilient societies. United Nations Headquarters, 25-26 January.

UNDP. (2020). Sustainable Development Goals in Nigeria. United Nations Development Programme (UNDP). Retrieved November 11, 2020, from https://www.ng.undp.org/content/nigeria/en/home/sustainabledevelopment-goals.html 
UNESCO. (2015). Not Just Hot Air: Putting Climate Change Education into Practice. Paris, UNESCO. 89pp. Retrieved November 12, 2020, from https://unesdoc.unesco.org/ark:/48223/pf0000233083

UNESCO. (2019). Inclusion in Education. United Nations Educational, Scientific and Cultural Organization (UNESCO). Retrieved November 11, 2020, from https://en.unesco.org/themes/inclusion-in-education/

UNFCCC. (2015). Adoption of The Paris Agreement. United Nations Framework on Convention of Climate Change. UNFCCC/CP/2015/L.9/Rev.1. Conference of the Parties (COP) Twenty-first session, Paris, 30 November to 11December 2015. 32pp. Retrieved November 13, 2020, from https://www.webcitation.org/6djDMHZAT?url=http://unfccc.int/resource/docs/2015/cop21/eng/109r01.pdf

Wambai, M. W. et al. (2017). Health effects of water shortage in Bogoro LGA, Bauchi State, Nigeria. Journal of Environmental Sciences, 18(I\&II).

Watts, N., Amann, M., Ayeb-Karlsson, S., Belesova, K., Bouley, T., Boykoff, M., Byass, P., Cai, W., CampbellLendrum, D., Chambers, J., Cox, P. M., Daly, M., Dasandi, N., Davies, M., Depledge, M., Depoux, A., Dominguez-Salas, P., Drummond, P., Ekins, P., Flahault, A., Frumkin, H., Georgeson, L., Ghanei, M., Grace, D., Graham, H., Grojsman, R., Haines, A., Hamilton, I., Hartinger, S., Johnson, A., Kelman, I., Kiesewetter, G., Kniveton, D., Liang, L., Lott, M., Lowe, R., Mace, G., Odhiambo, S. M., Maslin, M., Mikhaylov, S., Milner, J., Latifi, A. M., Moradi-Lakeh, M., Morrissey, K., Murray, K., Neville, T., Nilsson, M., Oreszczyn, T., Owfi, F., Pencheon, D., Pye, S., Rabbaniha, M., Robinson, E., Rocklo, J., Schutte, S., Shumake-Guillemot, J., Steinbach, R., Tabatabaei, M., Wheeler, N., Wilkinson, P., Gong, P., Montgomery, H., \& Costello, A. (2018). The Lancet Countdown on health and climate change: from 25 years of inaction to a global transformation for public health. Lancet, 391(10120), 581-630. https://doi.org/10.1016/S0140-6736(17)32464-9

WHO. (2020). Water, sanitation, hygiene and waste management for the COVID-19 Virus: Interim Guidance. World Health Organization (WHO) and the United Nations Children's Fund (UNICEF), 2020. WHO/2019nCoV/IPC_WASH/2020.3 (23 ${ }^{\text {rd }}$ April, 2020). Retrieved November 12, 2020, from http://www.google.com

\section{Copyrights}

Copyright for this article is retained by the author(s), with first publication rights granted to the journal.

This is an open-access article distributed under the terms and conditions of the Creative Commons Attribution license (http://creativecommons.org/licenses/by/4.0/). 